\title{
ERRATA, VOLUME XVII
}

p. 116 , line 6 from below: secclo. Read: secolo.

p. 117, line 20 from below: upāa äya' hi. Read: upāadāya' iti. line 7 from below: mutoditi. Read: mutoditit.

line 6 from below: mutodti. Read: mùtodit.

p. 118, note 2, line 1: Garuḍ Purāna. Read: Garuda Upanisad.

p. 274 , line 23 : aprés. Read: après.

p. 275 , line 6 from below: avaitattiré. Read: avait attiré. note 2 , line 1: met. Read: mit. 